University for Business and Technology in Kosovo

UBT Knowledge Center

UBT International Conference

2016 UBT International Conference

Oct 28th, 9:00 AM - Oct 30th, 5:00 PM

\title{
Treatment Possibilities of the Municipal Wastewaters in Ferizaj, Kosovo
}

\author{
Bekim Selimi \\ University for Business and Technology, bekim.selimi@ubt-uni.net
}

Follow this and additional works at: https://knowledgecenter.ubt-uni.net/conference

Part of the Engineering Commons

\section{Recommended Citation}

Selimi, Bekim, "Treatment Possibilities of the Municipal Wastewaters in Ferizaj, Kosovo" (2016). UBT International Conference. 16.

https://knowledgecenter.ubt-uni.net/conference/2016/all-events/16

This Event is brought to you for free and open access by the Publication and Journals at UBT Knowledge Center. It has been accepted for inclusion in UBT International Conference by an authorized administrator of UBT Knowledge Center. For more information, please contact knowledge.center@ubt-uni.net. 
TREATMENT POSSIBILITIES OF THE MUNICIPAL WASTEWATERS IN FERIZAJ, KOSOVO

\title{
TREATMENT POSSIBILITIES OF THE MUNICIPAL WASTEWATERS IN FERIZAJ, KOSOVO
}

\author{
Bekim Selimi \\ UBT College,Faculty of Civil Engineering-Construction and Infrastructure, 10000, \\ Prishtina, Kosovo \\ bekim.selimi@ubt-uni.net
}

\begin{abstract}
Kosovo has serious problems with the amount of water as well as their quality and the situation on the ground is quite alarming. There is no minimum wastewater treatment by collective pollutants nor by individual pollutants. As a result almost all wastewaters discharging to the rivers without any treatment deteriorating significantly their quality. The aim of this paper is to analyze the possibilities on finding solution to treat municipal waste waters in the Ferizaj town including villages. Municipality of Ferizaj performs wastewater discharge into the recipient without any prior treatment, which means directly into the river Neredime causing adverse effects in environment. Same situation is with 44 villages where collection of sewage is doing in septic tanks or discharging directly to the creek or river. Based on the configuration of the terrain can be build two main wastewater treatment plants consisting of secondary biological treatment, and one or two small WWTP's to include some villages that can not be connected to the main WWTP's. This paper presents the strategy for management of wastewater system, operational plans and methods for wastewater treatment comparing to the wastewater treatment plant in US Camp "Bondsteel" near Ferizaj. This research is intended to be taken effective measures for better management of waste water system and to raise awareness of the population in order to protect the environment.
\end{abstract}

Keywords: Waste Water Treatment Plant, Water quality, Waste Water discharge, Environment Protection

\section{Introduction}

The challenge of protecting human health and the environment where he lives, from pollution and risks from different bacterial and viral diseases, through the protection of surface water pollution, is the purpose of this paper.

Has been made a description of the current state of the sewerage system of wastewater, management options of the waters and proposals for a permanent solution to the problem of environmental pollution from wastewater. There are analyzed operational plans and methods for treatment and are made comparisons with the results of wastewater before and after treatment in wastewater treatment plant at US Camp "Bondsteel" near Ferizaj. Therefore, this research is intended to be taken effective measures for better management of waste water, rivers water and to raise awareness of the people in order to protect the environment and to preserve the flora and fauna of the river Neredime. 
Also mentioned possible methods of wastewater treatments such as primary treatment, secondary and tertiary, then processing and use of sludge and disinfection of wastewater after treatment respectively before discharge into the recipient or prior to their use for different purposes.

The last part mainly consists of possibility and hypotheses of wastewater treatment in Ferizaj municipality. There are presented conceptual projects for the construction of main collectors and the possibility of building the municipal wastewater treatment plants.

\section{Actual state}

Currently the town of Ferizaj owns three major collectors which collect wastewater. These three collectors discharging in two different locations in the river Neredime, first two collectors discharging in location near village Nekodim, while the third collector in location near the village of Varosh. Discharge of sewage from these three collectors in the recipient still is doing without any prior treatment, meaning directly to the river Neredime. Distribution network of sewage system at the moment is lying in about $90 \%$ of the town. Distribution networks and sewage system has a length of approximately $80 \mathrm{~km}$. The quality of waste water discharged into the recipient is not controlled by the respective institutions, sometimes individually for research purposes, which means that do not have concrete results for this water.

North part of Ferizaj, respectively the topography shows that this region has the slope in two directions. The fact that the river Neredime divided into two branches that tells us that this region has sloping in two directions, in the southern direction towards the southwestern flow of river Neredime (South basin) respectively towards the river Lepenc and the northern direction (North basin) downstream north river Sitnica. According to the latest information the Ferizaj municipality should have about 140,000 residents. The population density is 406 inhabitants per $1 \mathrm{~km}^{2}$. Municipalety of Ferizaj has 44 villages where is the nearly half of the population living in this municipality.

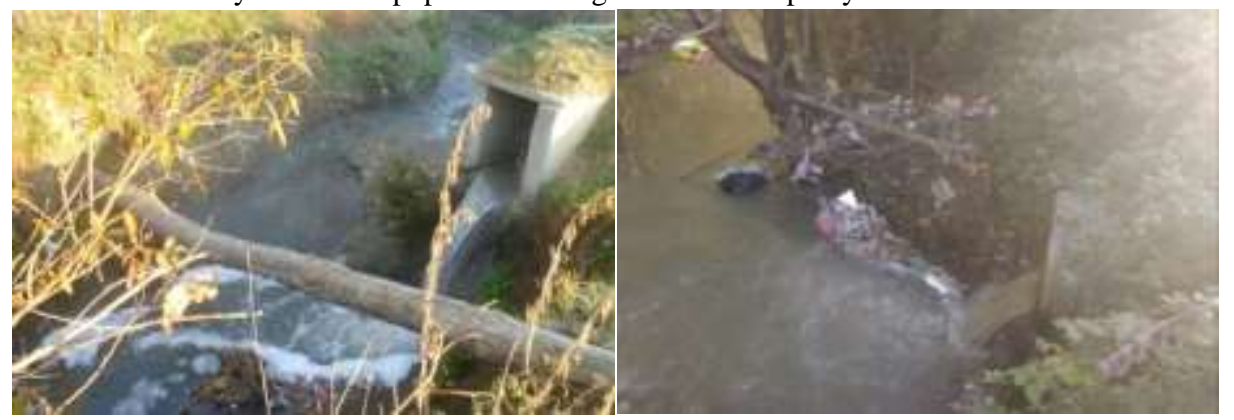

Fig 1: Location 1; sewage discharge near Ferizaj at the exit of village Varosh;

Location 2; sewage discharge near village Nekodim

One of the main sources of pollution of natural waters are discharges of wastewater, which contains chemicals that reduce the oxygen content in water, soluble compounds of phosphorus and nitrogen, favoring the process of eutrophication, bacteria and viruses pathogens, heavy metals and also substances that give them a bad odor. 
TREATMENT POSSIBILITIES OF THE MUNICIPAL WASTEWATERS IN FERIZAJ, KOSOVO

\section{Comparison of results}

Below shows the results of water (Table 1) from wastewater treatment plant in the US Camp "Bondsteel" near Ferizaj. This plant is the secondary type including three ponds or lagoons, which are supplied with oxygen at all times. Before discharging these waters are disinfected with chlorine. Water from the plant is used for cleaning of roads and sprinkling unpaved roads of Dust. Remain waters will be discharging into the creek flowing through the camp. Water for analysis is taken directly from the collector, then before entering the plant (influent) and prior to discharge to the recipient; this plant is not treating atmosferic waters.

Table 1: Water results from the influent and effluent of the WWTP in the US Camp 'Bondsteel' near Ferizaj on 15SEP2016.

\begin{tabular}{|l|l|c|c|c|}
\hline & \multicolumn{1}{|c|}{ Type of analyses } & Influent & Effluent & Unit \\
\hline 1 & COD & 540 & 27 & $\mathrm{mg} / \mathrm{L}$ \\
\hline 2 & CBOD5 & 386 & 2 & $\mathrm{mg} / \mathrm{L}$ \\
\hline 3 & Total Susp. Solids(TSS) & 220 & 2 & $\mathrm{mg} / \mathrm{L}$ \\
\hline 4 & Ammonia & 31 & 0 & $\mathrm{mg} / \mathrm{L}$ \\
\hline
\end{tabular}

The table shows that:

1. COD from $540 \mathrm{mg} / \mathrm{l}$ in influent, decreases to $27 \mathrm{mg} / \mathrm{l}$ in effluent,

2. CBOD5 from $386 \mathrm{mg} / \mathrm{l}$ in influent, decreases to $2 \mathrm{mg} / \mathrm{l}$ in effluent,

3. TSS from $220 \mathrm{mg} / \mathrm{l}$ in influent, decreases to $2 \mathrm{mg} / \mathrm{l}$ in effluent,

4. Ammonia from $31 \mathrm{mg} / \mathrm{l}$ in influent, decreases to $0 \mathrm{mg} / \mathrm{l}$ in effluent.

As shows, the cleaning of wastewater in the plant is at a satisfactory level. So, if the waters of the Ferizaj were treated in this way then there would be no environmental pollution, but we would have a clean and good environment for the development of flora and fauna.

\section{General information}

Rivers have been made collectors of all urban and industrial discharges. In regions with low population density problems of surface water pollution will be not perceptibly by reason of river self-cleaning ability, and if the rivers can't cope with direct discharges of urban waste water (untreated), this will result to negative effects on the water environment, the risk of infections, etc.

Natural water pollution from liquid waste is a critical environmental problem in many countries. Liquid waste may be sewage discharge, water runoff and industrial liquid discharges. In many urban localities sewage is collecting with rain waters and in some cases with liquid industrial waste (treated or untreated). There are discharging into rivers, lakes and seas, often without any special treatment, thus becoming a significant source of pollution.

There are two types of microorganisms: aerobic and anaerobic microorganisms. Aerobic microorganisms needed $\mathrm{O}_{2}$, while the anaerobic do not need $\mathrm{O}_{2}$. Aerobic biochemical processes occur 
Book of Proceedings

International Conference on Civil Engineering, Infrastructure and Environment

in the oxidation of organic substances containing N, P, C, S, mineral salts (carbonates, nitrates, sulfates) and carbonic acid. Aerobic processes mainly used for wastewater containing organic pollution in colloidal and dissolved state (biological cleaning of wastewater). [1]

Anaerobic bacteria can not live where oxygen is present. They use oxygen chemically combined such as nitrates (NO3) or sulphates ( $\left.\mathrm{SO}_{4}\right)$. These organism are active in anaerobic digestion and are associated with treatment processes to include: decomposition, odor and infections. [2]

Amount of oxygen against the unit volume of wastewater (in $\mathrm{mg} / 1 \mathrm{or} \mathrm{g} / \mathrm{m}^{3}$ ) that is required for mineralization of organic substances contained in them, up to the moment of stabilization, marked with BOD and called biochemical oxygen demand.

To have soon BOD results will determine amount of oxygen spent after 5 days considering that between BOD20 and BOD5 (for municipal water) exists ratio BOD20=1.1: 1.5 BOD5.

\section{Methods of wastewater treatment}

Increase concentration of population in urban centers and increase demands of population and industry for water, on the one hand, and the reduction and impairment of water reserves, has become the treatment of wastewater an acute problem in many of the countries.

Complex question that Engineer designers or public health officials facing is: what level of treatment should be applied to ensure the protection of public health and the environment? The answer to this question requires knowledge of local conditions and needs, the application of scientific knowledge and engineering evaluation based on previous experience, considering the central and local regulations.

Nowadays, operating units and processes are grouped together to bring different levels of treatments knowing as preliminary, primary, secondary and advanced. [3]

As shows below (Figure 2) has been submitted a project proposal for the wastewater treatment plant (model) including primary and secondary treatment respectively mechanical and biological treatment of wastewater.

At least biological treatment or equivalent processes should be applied to municipal waste water, where necessary and a step by step progression. [4] 
TREATMENT POSSIBILITIES OF THE MUNICIPAL WASTEWATERS IN FERIZAJ, KOSOVO

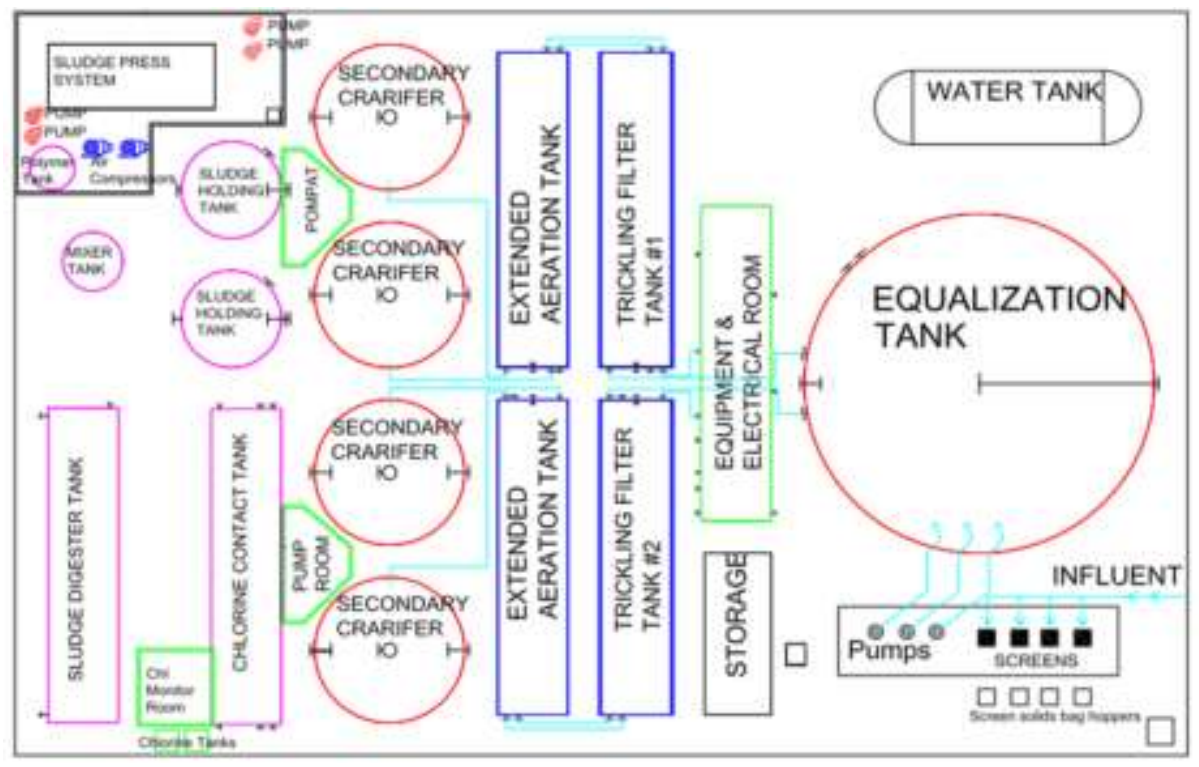

Fig 2: Proposed WWTP

\subsection{Processing and use of sludge}

In the process of cleaning / treating wastewater, can be created another problem: sludge. As with the higher the degree of wastewater treatment more waste sludge should be generated. Sludge is generated by the residual substances from wastewater and solids generated during the process of wastewater treatment. Basic processes for sludge treatment are as follows: drainage, stabilization, conditioning, dewatering and reduction. [5] Wastewater sludge is composed by organic matter and contains significant amounts of useful subjects, like nitrogen, phosphorus, potassium. But fresh sludge smells bad and is very dangerous because it contains a large number of different microbes (including pathogens) and transported with difficulty, because there is to much humidity. Wastewater sludge contains also the many bacteria, viruses, parasites that can cause quite endemic diseases as well as large amounts of toxic elements, much more than these elements found in the soil. Therefore the use of sludge as a fertilizer in agriculture should be done with special care and can't be considered a satisfactory solution to the problem. [6]

\subsection{Composting}

Remain wastes from the plant processes (treated or untreated sludge) are poison for operating personnel. This waste can be dumped or used for specific purposes. Several methods can be harmful to the environment such as burning, dumping at sea, etc. But the most accepted method is sludge processing respectively composting and use for agriculture purposes.

Composting is a method of recycling organic materials such as food waste, plant waste, rotten fruits, grass, branches of trees (greenery in general), shredded paper, sludge from the wastewater treatment 
Book of Proceedings

International Conference on Civil Engineering, Infrastructure and Environment

(if it exists), etc. During the decomposition, the organic materials transfer to some substances, as nutrient-fertilizer using in agriculture. [7]

\subsection{Disinfection}

After decantation process and prior to discharge to the basin, sewage should be disinfected as set by the sanitary inspectors to protect the basins by the possibility of contamination with pathogenic bacteria.

Disinfection is one of the critical components of treating wastewater to protect public health. River or any other aqueous area accepting wastewater discharges of inadequately disinfected wastewaters may be contaminated by pathogenic organisms (disease causers). People can be exposed to these pathogens due to drinking water, consumption of fishes or other water organisms, eating crops irrigated with these waters, or during other activities in contact with water, such as swimming or fishing.

\section{Conclusion}

Sewer is discharging into the River Neredime in both streams without any prior treatment causing chemical and biological pollution of the Neredime River. According to the analysis and plans, first needed to build sewer systems for the villages which currently have no system for sewage disposal. After that in a medium-term framework should be built two collectors, north colector which will collect sewage from the northern part of the city and villages and southwest collector who will gather wastewater from the southwest of the city and villages. It is necessary that all buildings have built separate sewage system from the atmosferic water systems.

In case there is one system of wastewater and atmospheric, then will be difficult for their treatment by reason that due to storm water runoff in large quantities plant can not accept all these flows; otherwise should increase the size of the treatment plant. But the most reasonable is that all localities have separate sewer system and this will enable lower cost of construction of the plant as well as lower operating costs. So, according to the terrain configuration of Ferizaj wastewater will be collected in two locations, and at this locations planning to build WWTP's.

Southwest collector will be lied till the outskirts of the village Varosh or near the village Gurëz where it will build the WWTP and then flowing into the southern branch of the river Neredime which branch continues further towards Kacanik and flows into the river Lepenc.

The north collector will end at the exit of the village Bablak where is planning to build the second WWTP and then flowing into the northern branch of the river Neredime, near the river outfall of Sitnica River. Outside these collectors can remain some villages in the eastern part that according to preliminary plans can not be involved in these projects. After more studies and detailed measurements will look for the possibility of including these villages in one of these collectors. Otherwise it will consider the possibility of building a third WWTP in this area. 


\section{TREATMENT POSSIBILITIES OF THE MUNICIPAL WASTEWATERS IN FERIZAJ,}

KOSOVO

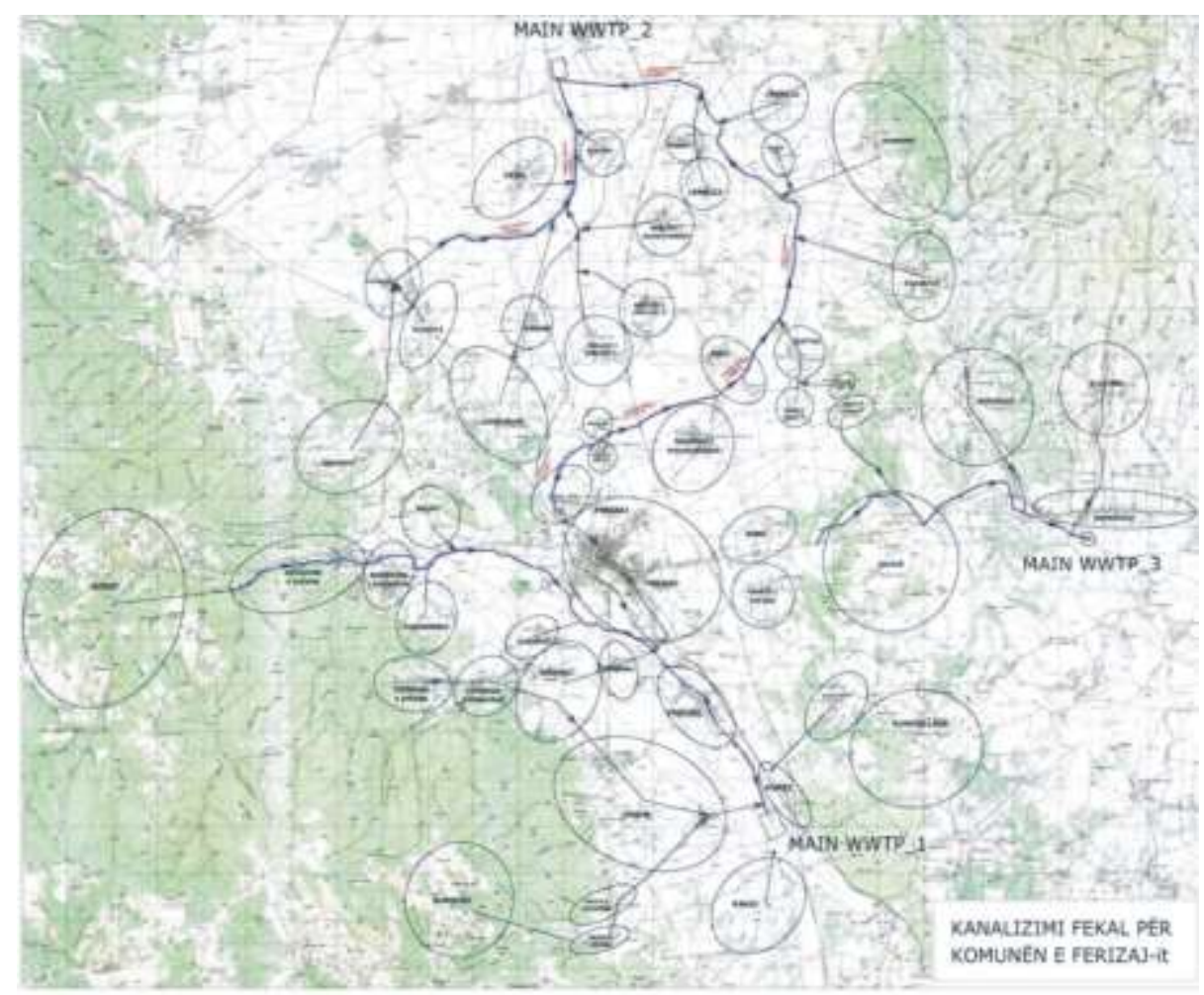

Fig 3: Southwestern and Northern collector of the Ferizaj Municipalety

The treated water from the plant, after can be used for different purposes such as: land irrigation, irrigation of parks, irrigation of crops, fire protection, street washing, etc.

Pollution knows no national boundaries. Pollutants emitted in one place, by air, streams of water, food and in other ways, spreading to large distances, and often attacking the countries that are not sources of pollution. Environmental pollution by volume, types and consequences has reached such proportions that it has become the concern of all humanity. [8]

With tendency that Kosovo move towards European integration, it must act to fulfill the preconditions for ratification of as many environmental conventions and protocols. Since almost all Kosovo rivers flowing outside its borders, the Republic of Kosovo must pay attention to maintaining the quality of these waters and especially the possibility of ratification of the Helsinki Convention on the protection and use of transboundary watercourses and international lakes.

The problem of discharging uncontrolled sewage, lack of funds of municipal companies or local governments, the inadequate legislation same as the EU countries, no political actions to solve the problem, the lack of strategy for solving this problem, no awareness raising to the people of this area, all of these are a motive for discussion of opportunities for the construction of WWTP's and which urgently requires solution 
Book of Proceedings

International Conference on Civil Engineering, Infrastructure and Environment

Kosovo future generations will face a bill of negligence from the past. Pollution, funds misapplication, damaged and contaminated areas, this is not the legacy that the current generation wants to leave to the future.

\section{References}

1. Rexhepi, N. (2006), Mbrojtja e ambientit për jetë më të mirë, Prishtinë.

2. Texas Engineering Extension Service, Water and Wastewater Training Program, Unit I \& II .

3. Metcalf \& Eddy (2003), Wastewater Engineering-Treatment and Reuse, Fourth Edition, Mc Graw Hill, New York.

4. Convention on the protection and use of transboundary watercources and international lakes, Helsinki, 1992.

5. Mackenzie, L.D. \& Cornwell, A.D. (2008), Introduction to Environmental Engineering, Fourth Edition, Mc Graw Hill, New York.

6. Çullaj, A. (2005), Kimia e Mjedisit, Tiranë. pp.153.

7. Midwest Bio-Systems, Inc., The production of Humified Compost, ACS Compost Workshop

8. Rozhaja, D. \& Jablanoviq, M. (1983), Ndotja dhe mbrojtja e ambientit jetësor, ETMM, Prishtinë. 